\title{
Variation in Pipetting May Lead to the Decreased Detection of Antibodies in Manual Gel Testing
}

\author{
SHARON BOBRYK, LINDA GOOSSEN
}

BACKGROUND: Variation in pipetting technique can contribute to the failed detection of weakly reactive antibodies. This study evaluated the impact of pipetting technique on the sensitivity of antibody detection using the manual gel test.

STUDY DESIGN AND METHODS: A total of 115 plasma antibodies were evaluated using the manual gel test (Ortho ID-MTS, Raritan, NJ). All antibodies were diluted to obtain $1+, \mathrm{w}+$, and undetectable reactions. Testing was performed in parallel using two pipetting techniques: cells and plasma pipetted into the gel card to allow an air gap and without an air gap.

RESULTS: When cells and plasma were pipetted into the gel card without air gap, $12.4 \%$ of $1+$ reactions $(\mathrm{p}<0.001)$ and $81.0 \%$ of $\mathrm{w}+$ reactions $(\mathrm{p}<0.001)$ were not detected. Overall, $24.7 \%$ of clinically significant $(\mathrm{p}<0.001)$ and $29.7 \%$ of nonspecific antibodies $(\mathrm{p}<0.05)$ became nonreactive. Antibody screening tests failed to detect $26.0 \%$ of passively acquired anti-D $(\mathrm{p}<0.001), 38.0 \%$ of anti-E $(\mathrm{p}<0.001), 28.0 \%$ of anti$\mathrm{Jk}^{\mathrm{a}}(\mathrm{p}<0.001), 20.0 \%$ of anti-K $(\mathrm{p}<0.05)$, and $35.0 \%$ of warm auto antibodies $(\mathrm{p}<0.05)$.

CONCLUSION: Cells and plasma pipetted manually without leaving an air gap in the gel card failed to detect clinically significant antibodies. An optimal pipetting technique is recommended to ensure the detection of weakly reactive antibodies.

INDEX TERMS: Manual Pipetting, Gel Testing, Antibodies

Clin Lab Sci 2011;24(3):161

Sharon Bobryk, MSA, MLS(ASCP)SBB ${ }^{C M}$, Beaumont Laboratory, Royal Oak, $M I$
Linda Goossen PhD, MT (ASCP), College of Health

Professions, Grand Valley State University, Grand Rapids, $M I$

Address for Correspondence: Sharon Bobryk, MSA, $M L S(A S C P) S B B^{C M}$, Medical Laboratory Scientist, Clinical Pathology, Blood Bank, Beaumont Laboratory, 3601 W. 13 Mile Road, Royal Oak, MI 49313, (248) 898-9010, sharon.bobryk@beamont.edu

\section{INTRODUCTION}

Since its inception by Lapierre et $\mathrm{al}^{1}$ in 1988, the gel test has revolutionized pretransfusion testing and become a widely-used serological testing method in immunohematology laboratories worldwide. The benefits of using gel for antibody screening have been widely published and include ease of use, reduced number of procedural steps, reduced sample size, ease of reaction readability, and increased antibody detection sensitivity. ${ }^{2-5}$ In order to optimize these benefits, variability in the test procedure must be controlled when performing the manual gel test.

According to the AABB Technical Manual, it is imperative that antibody detection systems used by each laboratory be sufficiently sensitive. ${ }^{6}$ Studies have provided evidence that the gel antibody screen has increased sensitivity over previously established antibody screening methodologies $5,7,8$ and aids in the early detection of weak antibodies using relatively small amounts of patient plasma. The package insert of the Ortho ID-MTS gel system (Raritan, NJ) recommends adding $50 \mu \mathrm{L}$ of $0.8 \%$ red blood cells and $25 \mu \mathrm{L}$ of patient plasma; ${ }^{9}$ however, given the small volumes of reactants, caution must be exercised in order to ensure high sensitivity of the reaction. 


\section{RESEARCH AND REPORTS}

Antigen-antibody reactions can be affected by a number of variables including antigen concentration, temperature, incubation time, ionic strength, and $\mathrm{pH} .{ }^{10}$ However, one variable that is not specified in the gel test instructions for use is the manual pipetting technique. Although laboratorians pipette frequently, formal training is often taken for granted and operator variation in pipetting technique has been shown to be a contributing factor in laboratory error. ${ }^{11}$ Variation in pipetting technique decreases the sensitivity of the antibody screening tests, thus increasing the probability of failure to detect an antibody, ${ }^{12}$ particularly if the antibody is weakly reactive. These false-negative antibody screening results pose a high risk for patients; ${ }^{13}$ it has been well documented that the failure to detect weakly reactive red cell alloantibody can lead to a rapid anamnestic production of antibody and delayed hemolytic transfusion reactions. ${ }^{6}$ In 2009 alone, the Food and Drug Administration received 74 reports of transfusion recipient fatalities, $27.0 \%$ of which were hemolytic transfusion reactions due to single or multiple clinically significant antibodies that were not detected in pretransfusion testing. ${ }^{14}$

Although the manufacturer's instructions for use state that the mixture of patient plasma and reagent red blood cells "may or may not touch the gel suspension" during incubation, ${ }^{15}$ it is hypothesized that weakly reactive antibodies may not be detected when the air gap between the plasma-cell mixture and the gel is eliminated by an "improper" pipetting technique. This study evaluated the effects of pipetting technique in manual gel antibody detection using the Ortho IDMTS gel system. By maintaining the air gap and vertically pipetting plasma during the incubation process of the gel card, improved detection of weakly reactive clinically significant antibodies could be achieved.

\section{MATERIALS AND METHODS}

A total of 115 plasma samples containing antibodies were evaluated using the manual gel test, resulting in 876 antibody screen reactions. The 115 samples contained 43 different antibody specificity combinations, of which 21 were single antibodies directed to the antigens $\mathrm{c}, \mathrm{C}, \mathrm{D}$, passively acquired anti$\mathrm{D}$ (Dpass), e, E, Fy ${ }^{\mathrm{a}}, \mathrm{Fy}^{\mathrm{b}}, \mathrm{Jk}^{\mathrm{a}}$, Jk${ }^{\mathrm{b}}, \mathrm{K}, \mathrm{Knops}$ system, Le'
$\mathrm{M}, \mathrm{N}, \mathrm{S}$, and s. Other antibodies with no apparent specificity (nonspecific) tested included warm autoantibodies, cold-reactive antibodies, warm-reacting $\mathrm{IgG}$, and antibodies to low-prevalence antigens.

All plasma samples were previously tested for antibodies using the gel method and showed a range of w+ (weak) to $3+$ in reactivity on the reaction grading scale of $\mathrm{w}+$ to $4+$. While the majority of samples contained antibodies of known specificity, several nonspecific antibodies were included in this study to mimic true patient antibody screen testing conditions for unexpected antibodies. Samples with multiple antibodies were tested using selected reagent screening cells such that reactivity could be attributed to only single antibody specificity.

Two lots of in-date $0.8 \%$ reagent screening cells (Ortho, Raritan, NJ) with identical phenotypes were used. Quality control was performed daily on reagent red blood cells and gel cards. Antibody samples were diluted with $6.0 \%$ albumin in an initial $2: 3$ dilution, followed by subsequent $1: 3$ dilutions to obtain three final reactions of $1+, w_{+}$, and 0 on the gel system to establish endpoints.

Each antibody was tested with screening cells at undiluted, 1+, w+ and 0 reaction strengths. The neat and diluted antibodies were pipetted in tandem using two pipetting techniques. In Technique $\# 1,50 \mu \mathrm{L}$ of $0.8 \%$ reagent screening cells was pipetted into the microwell of the gel card at a $45^{\circ}$ angle and aimed at the bowl wall, thus allowing an air gap between the screening cells and the dextran acrylamide gel (Figure 1). Twenty-five $\mu \mathrm{L}$ of plasma containing antibody was then pipetted vertically into the microwell. Care was taken to avoid touching the tip of the pipette to the microwell. In Technique $\# 2,50 \mu \mathrm{L}$ of $0.8 \%$ reagent screening cells was pipetted vertically into the microwell, allowing the red blood cell suspension to fall into the column of the microwell and rest directly on the top of the dextran acrylamide gel. Technique \#2 represents the elimination of the air gap between the cells and the gel column (Figure 1). Twenty-five $\mu \mathrm{L}$ of plasma containing antibody was then pipetted at a $45^{\circ}$ angle at the bowl wall of the microwell. Care was taken in pipetting to ensure that the tip of the pipette did not 


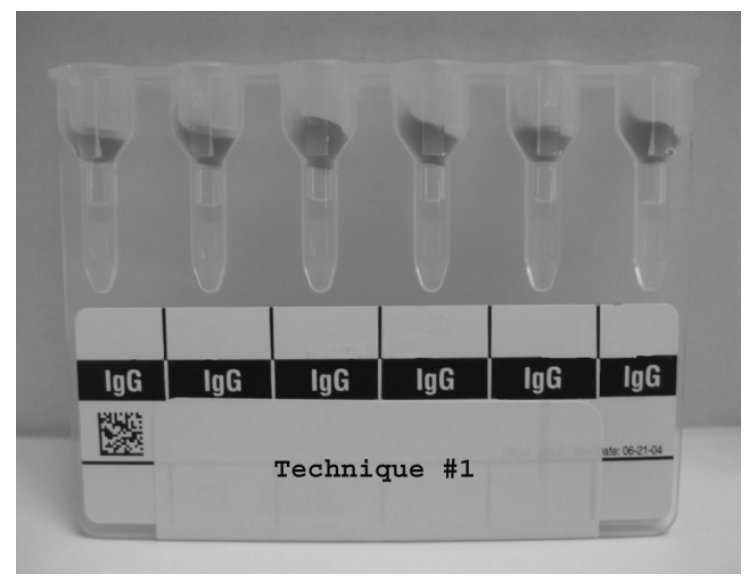

A. Screening Cells Pipetted Using Technique \#1 (With Air Gap).

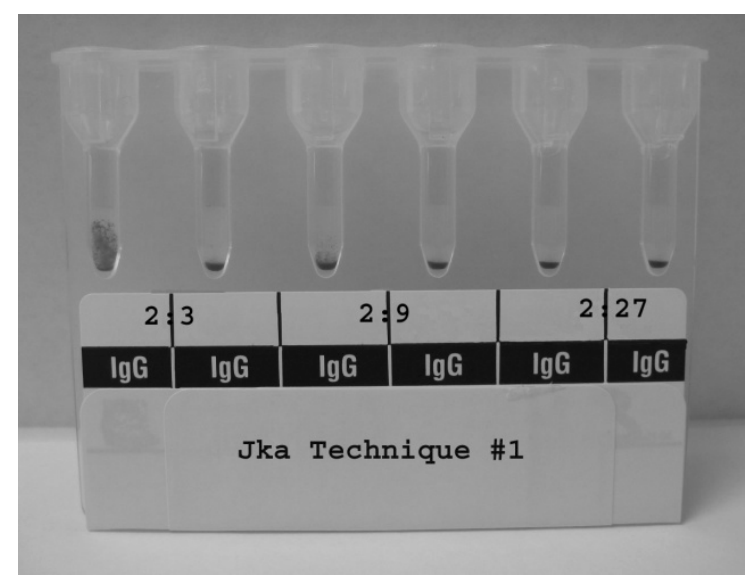

C. Anti-Jka Reaction After Centrifugation Using Technique \#1

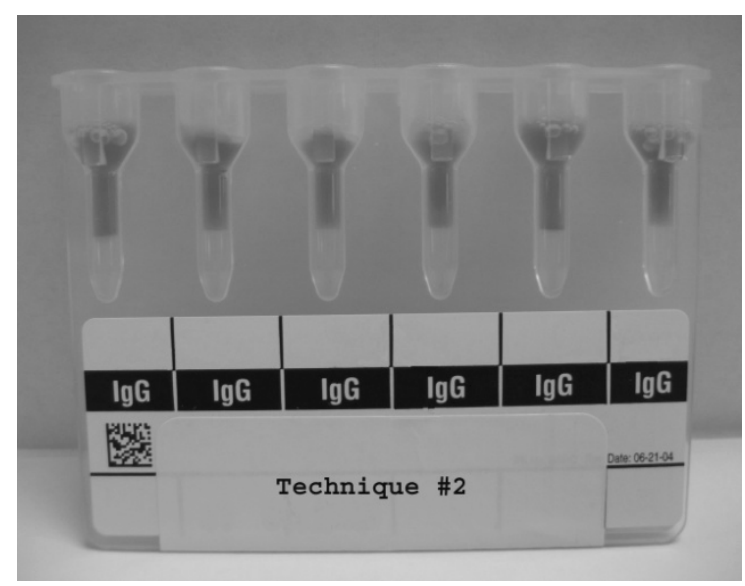

B. Screening Cells Pipetted Using Technique \#2 (No Air Gap)

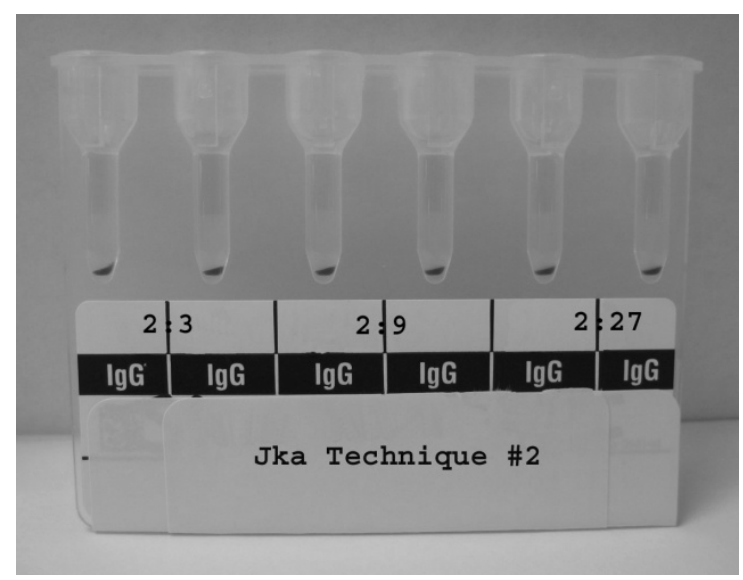

D. Anti-Jk Reaction After Centrifugation Using Technique \#2

Figure 1: Screen Cell Pipetting Technique \#1 (with air gap) and Technique \#2 (without air gap) with Reaction Comparisons

touch the microwells, as directed in the Ortho instructions.

The gel cards of both pipetting techniques were incubated simultaneously at $37^{\circ} \mathrm{C}$ for 15 minutes in an MTS incubator (Pompano Beach, FL). The cards were then centrifuged at the preset speed and time of 3400 rpms (135.1 g force) for 10 minutes (Figure 1). Cards were read, graded, and interpreted by comparing with the MTS gel grading chart. Each graded reaction was scored using the following scoring assignment: 5 for $1+, 3$ for $\mathrm{w}^{+}$, and 0 for undetectable reactions.

\section{Statistical Analysis}

Data were statistically analyzed using paired t-test. The level of significance was established at $\mathrm{p}<0.05$.
Table 1: Reaction Comparison of Pipetting Techniques - By Reaction Strength

Reactivity: Pipetting Technique \#1 vs Technique \#2

\begin{tabular}{|c|c|c|c|c|c|c|}
\hline & \multicolumn{2}{|c|}{ All $1+\& \mathrm{w}+^{*}$} & \multicolumn{2}{|c|}{$1+^{*}$} & \multicolumn{2}{|c|}{$\mathbf{w +}{ }^{*}$} \\
\hline $\mathrm{n}$ & \multicolumn{2}{|c|}{234} & \multicolumn{2}{|c|}{129} & \multicolumn{2}{|c|}{105} \\
\hline Mean \& & \multirow{2}{*}{\multicolumn{2}{|c|}{$\begin{array}{l}4.1+/-1.0 \\
2.3+/-4.6\end{array}$}} & \multirow{2}{*}{\multicolumn{2}{|c|}{$\begin{array}{c}5.0+/-0 \\
3.7+/-2.9\end{array}$}} & \multirow{2}{*}{\multicolumn{2}{|c|}{$\begin{array}{c}3.0+/-0 \\
0.6+/-1.7\end{array}$}} \\
\hline Variance & & & & & & \\
\hline Same rxn & 81 & $34.6 \%$ & 64 & $49.6 \%$ & 18 & $17.2 \%$ \\
\hline Weaker rxn & 48 & $20.5 \%$ & 48 & $37.2 \%$ & 0 & NA \\
\hline Stronger rxn & 4 & $2.0 \%$ & 1 & $0.8 \%$ & 2 & $1.9 \%$ \\
\hline Missed rxn & 101 & $43.2 \%$ & 16 & $12.4 \%$ & 85 & $81.0 \%$ \\
\hline $\mathrm{p}$ values & \multicolumn{2}{|c|}{$<0.001$} & \multicolumn{2}{|c|}{$<0.001$} & \multicolumn{2}{|c|}{$<0.001$} \\
\hline
\end{tabular}

${ }^{*} \mathrm{p}<0.001$ 


\section{RESEARCH AND REPORTS}

\section{RESULTS}

Results of the 438 parallel tests were evaluated using the paired t-test. Table 1 shows that using Technique \#2, $43.0 \%(101 / 234)$ of $1+$ and $\mathrm{w}+$ reactive antibodies became nonreactive when compared to their Technique \#1 counterparts $(\mathrm{p}<0.001)$. Of the $43.0 \%$ of affected reactions with Technique \#2, 12.4\% (16/129) of the $1+$ reactions $(\mathrm{p}<0.001)$ and $81.0 \%(85 / 125)$ of the $\mathrm{w}+$ reactions $(\mathrm{p}<0.001)$ became nonreactive.

An antibody is considered clinically significant if antibodies of its specificity have been associated with hemolytic disease of the fetus and newborn, with a hemolytic transfusion reaction, or with a decrease in red blood cell survival. ${ }^{6}$ Clinically significant antibodies tested in this study included anti-c, -C, -D, -e, -E, -Fy', $-\mathrm{Fy}^{\mathrm{b}},-\mathrm{Jk}^{\mathrm{a}},-\mathrm{Jk} \mathrm{k}^{\mathrm{b}},-\mathrm{K},-\mathrm{S}$, and $-\mathrm{s}$. The results of this study showed that the detection of clinically significant antibodies was significantly affected; Technique \#2 (pipette without air gap) failed to detect $24.7 \%$ $(70 / 234)$ of these antibodies $(\mathrm{p}<0.001)$. Clinically insignificant antibodies evaluated in this study included cold-reactive antibodies, anti-D (passive), anti-Knops, anti-Le ${ }^{\mathrm{b}},-\mathrm{M}$, and $-\mathrm{N}$. Testing results showed no significant difference in antibody detection between the two pipetting methods for these specificities $(\mathrm{p}>0.05)$. However, it was interesting to note that $6.8 \%(8 / 117)$ of clinically insignificant antibodies resulted in stronger reactions using pipetting Technique \#2. When pipetted using Technique \#2, 29.7\% (11/37) of nonspecific antibodies (warm auto antibodies, antibodies to lowprevalence antigens, and warm IgG antibodies) became nonreactive $(\mathrm{p}<0.05)$ (Figure 2$)$.

When reactions of the gel cards pipetted using Technique \#2 were analyzed for single antibody specificities, $26.0 \%(16 / 61)$ of passively-acquired anti-D ( $\mathrm{p}<0.001), 38.0 \%(23 / 60)$ of anti-E $(\mathrm{p}<0.001), 28.0 \%$ $(17 / 61)$ of anti-Jk $\mathrm{J}^{\mathrm{a}}(\mathrm{p}<0.001), 20.0 \%(11 / 56)$ of anti-K $(\mathrm{p}<0.05)$, and $35.0 \%(6 / 17)$ of warm auto antibodies $(\mathrm{p}<0.05)$ became nonreactive. Although only a small number of anti-e and antibodies to low-prevalence antigens were evaluated, results showed $50.0 \%$ (4/8, $1 / 2$ ) became nonreactive and $100.0 \%(10 / 10)$ of anti-S became weaker when pipetting Technique \#2 was used. Figures $1 \mathrm{c}$ and Figure 1d show the images of reaction results for a sample of anti-J $\mathrm{k}^{\mathrm{a}}$ pipette using Technique
\#1 (with air gap) and Technique \#2 (without air gap), respectively.

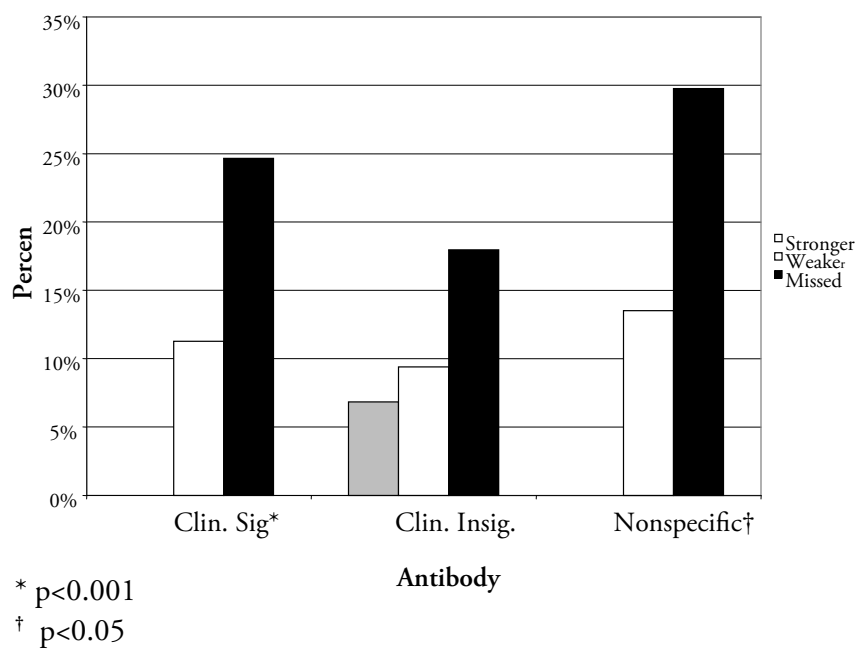

Figure 2: Reaction Comparison of Pipetting Technique \#1 vs. Technique \#2 - By Clinical Significance of Antibodies

\section{DISCUSSION}

The results of this study clearly showed that when plasma and reagent screening cells were pipetted using Technique \#2 (plasma pipetted at a $45^{\circ}$ angle and elimination of the air gap between reagent cells and the dextran gel), clinically significant antibodies were not detected. Of the 234 tests that were diluted to $1+$ and $\mathrm{w}+$ reactivity, $43.0 \%(\mathrm{p}<0.001)$ became nonreactive and $21.5 \%$ were weakened when serum and cells were pipette using Technique \#2. Specifically, $12.4 \%$ of all $1+$ reactions $(\mathrm{p}<0.001)$ and $81.0 \%$ of all $\mathrm{w}+$ reactions $(\mathrm{p}<0.001)$ became completely undetectable when pipetted using Technique \#2.

The incubation phase is the only time when patient plasma and reagent screening cells come into direct contact. When plasma is not pipetted vertically into the microwell and the reagent screening cells fall through the column during incubation, the spatial distance between the plasma resting in the bowl of the microwell and the majority of the screening cells in the column is increased. This disequilibrium of serum and cells not only inhibits proper incubation due to the changes in spatial distance and possible uneven heat distribution in the reaction in the microwell, but also causes the reagent screening cells to begin impregnating the gel suspension prior to centrifugation. 


\section{RESEARCH AND REPORTS}

This study showed that with pipetting Technique \#2 (with no air gap), $24.7 \%$ of clinically significant antibodies failed to be detected in manual gel antibody screening tests and $11.3 \%$ of reactions were weaker than their Technique \#1 counterparts $(\mathrm{p}<0.001)$. The inability to detect clinically significant antibodies could place patients at an increased risk for developing a hemolytic transfusion reaction. In addition, the weakening of reactivity with Technique \#2 could lead to an increased incidence of unidentifiable nonspecific antibodies. There was also an apparent increased detection of clinically insignificant antibodies, but not at the level of statistical significance. This increase in detection of clinically insignificant antibodies can result in considerably more time, effort, and additional testing ${ }^{16}$ to be expended by the laboratorian, with little additional benefit to the patient when providing a timely and safe transfusion. ${ }^{8}$

No single serological antibody screening technique can provide the optimum reaction conditions for all red cell specificities. $^{2,9}$ The results of this study are consistent with previous studies with regard to individual antibody specificities. Antibodies to some antigens in the Rh, Kidd, and Kell systems have been reported to be nonreactive in gel. ${ }^{3,5,8,13}$ It is important to note, this study found these specificities to be even more susceptible to nondetection when the variable of pipetting technique is factored into the equation.

This study was limited by the number of antibody specificities available for testing; $\mathrm{p}$-values could only be established for the specificities of passively acquired anti-D $(\mathrm{p}<0.001)$, anti-E $(\mathrm{p}<0.001)$, anti-K $(\mathrm{p}<0.05)$, anti-Jk $(\mathrm{p}<0.001)$, and warm auto antibodies $(\mathrm{p}<0.05)$. Antibody specificity was limited to the patient mix at the testing facility during the time of study and the quantity of positive samples received. Some low-volume specimens did not yield enough plasma for multiple testing to be performed and thus generated a limited number of reactions.

Although automation may eliminate some pipetting variability of the gel antibody screen, in critical timesensitive transfusion emergencies, automation might not be readily available and the value of a properly trained, highly skilled medical laboratory scientist is indispensable. The laboratorian performing manual gel antibody screens needs to be mindful that pipetting technique and preservation of the air gap is a controllable variable when using the manual gel technique for antibody detection. Based on the results of this study, it is recommended that an optimal pipetting technique be adopted in antibody detection testing to avoid the failure to detect clinically significant antibodies in all manually pipetted gel antibody screens. Reagent screening cells should be pipetted at a $45^{\circ}$ angle and aimed at the bowl wall of the microwell to preserve the air gap between screening cells and the gel suspension, followed by the vertical pipetting of patient plasma. Although the manufacturer's instructions for use cannot account for all errors that could be introduced into the test system, it is suggested that the statement "may or may not touch the gel suspension" be further evaluated for validity with regards to the detection of clinically significant antibodies.

Acknowledgements: Thank you to Clare Wong and the Gulf Coast Regional Blood Center School of Blood Bank Technology for their assistance in this research.

\section{REFERENCES}

1. Lapierre Y, Rigal D, Adam J, et al. The gel test: a new way to detect red cell antigen-antibody reactions. Transfusion 1990;30:109-13.

2. Leitch K, Forrest A, Mitchell R. A preliminary trial of the gel test for blood group serology. Br J Biomed Sci 1993;50:64-6.

3. Judd WJ, Steiner EA, Knafl PC, Masters C. The gel test: use in the identification of unexpected antibodies to blood group antigens. Immunohematology. 1998;14:59-62.

4. Chanfong SI, Hill S. Comparison of gel technology and red cell affinity column technology in antibody detection. Immunohematology 1998;14:152-4.

5. Shin JH, Lee JY, Kim JH, Kim HR, Lee JN. Screening and identification of unexpected red cell antibodies by simultaneous LISS/Coombs and $\mathrm{NaCl} /$ Enzyme gel methods. J Korean Med Sci 2009;24:632-5.

6. Roback JD, Combs MR, Grossman BJ, Hillyer CD, eds. Technical manual. 16 ${ }^{\text {th }}$ ed. Bethesda MD: AABB, 2008.

7. Eichler H, Böhler A, Hastka J, Richter E, Kerowgan M, Goldmann SF. Micro-column affinity test and gel test: comparative study of two techniques for red cell antibody screening.Vox Sang 1999;77:154-8.

8. Casina TS. In search of the Holy Grail: comparison of antibody screening methods. Immunohematology 2006;22:196 -202 .

9. ID-Micro Typing System ${ }^{\mathrm{TM}}$ Implementation Guide and Procedures (J6902201). Ortho Clinical Diagnostics. 
10. Beattie KM. Control of the antigen-antibody ratio in antibody detection/compatibility tests. Transfusion 1980;20:277-84.

11. Vaccaro W. Minimizing liquid delivery risk: operators as sources of error. Am Laboratory 2007;39:16-17.

12. Greendyke RM, Wormer JL, Banzhaf JC. Quality assurance in the blood bank. Studies of technologist performance. Am J Clin Pathol 1979;71:287-90.

13. Powers A, Chandrashekar S, Mohammed M, Uhl L. Identification and evaluation of false-negative antibody screens. Transfusion 2009;50:617-21

14. Fatalities Reported to FDA Following Blood Collection and Transfusion: Annual Summary for Fiscal Year 2009. Washington, DC: U.S. Department of Health and Human
Services, Food and Drug Administration, Center for Biologics Evaluation and Research (CBER). [Available from: http://www.fda.gov/BiologicsBloodVaccines/SafetyAvailability/ ReportaProblem/TransfusionDonationFatalities/ucm204763.h tm\#HTR (accessed 2010 April 22).]

15. Ortho ID-Micro Typing System ${ }^{\mathrm{TM}}$ Instructions for Use AntiHuman Globulin Anti-IgG (Rabbit) MTS Anti-IgG card $^{\mathrm{TM}}$. (Ref MTS084024). Ortho Clinical Diagnostics.

16. Combs MR, Bredehoeft SJ. Selecting an acceptable and safe antibody detection test can present a dilemma. Immunohematology 2001;17:86-9.

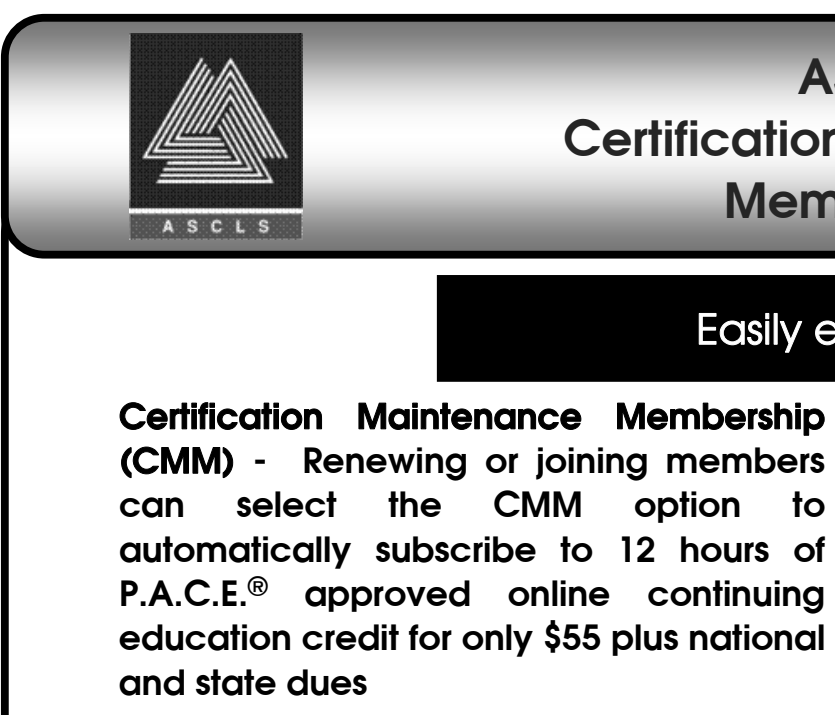

CMM is a 1 year subscription with MediaLab,

Inc.

the 12 courses cover designated discipline areas for the Board of Certification (BOC) Certification Maintenance Program

\section{Certification Maintenance Membership (CMM) - Renewing or joining members automatically subscribe to 12 hours of P.A.C.E. approved online continuing and state dues}

ASCLS Membership

\section{Easily earn CE credit}

\section{For more information, visit http://www.ascls.org/cmm or email joanp@ascls.org.}

\begin{abstract}
Certification Maintenance Membership Plus (CMMP) - upgrade to unlimited hours of CE and select the courses you want for $\$ 95$ plus national and state dues; 1 year subscription
\end{abstract}

